\title{
Comparison of total knee arthroplasty after combined high tibial osteotomy with a matched group of primary total knee arthroplasty
}

\author{
Kombine yüksek tibial osteotomiden sonra total diz artoplastisi ile \\ primer total diz artroplastisinin karşılaştırılması
}

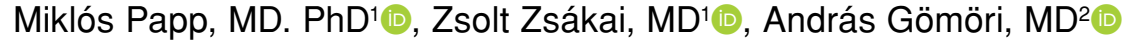 \\ 1'Department of Orthopaedic Surgery, Borsod County Teaching Hospital, Miskolc, Hungary \\ ${ }^{2}$ Department of Traumatology, Borsod County Teaching Hospital, Miskolc, Hungary
}

\begin{abstract}
Objectives: This study aims to compare the results of total knee arthroplasties (TKAs) performed after previous combined high tibial osteotomy (CO) to those of a matched control group of primary TKA.
\end{abstract}

Patients and methods: Between 01 August 2006 and 31 December 2011, we performed 24 consecutive cemented TKAs in 24 patients (10 males, 14 females; mean age 69.5 years; range, 60 to 79 years) who had undergone previous CO (study group). The study group was compared to a control group of 24 patients (10 males, 14 females; mean age 69.9 years; range, 63 to 79 years) who were performed primary TKA during the same period. Pre- and postoperative The Knee Society knee and function score and range of movement were determined. The femorotibial angle, the distance between the tangent to the lateral subchondral plate and the top of the fibular head, the transposition of the tibial condyle, the length of the patellar tendon and the tibial slope angle were measured preoperatively. At final follow-up, the same parameters were calculated and the amount of lateral tibial bone resection was determined.

Results: The mean follow-up duration was 97 months (range, 61 to 124 months) in the study group and 97 months (range, 61 to 123 months) in the control group. TKA survivorship rate was $100 \%$ in both groups. At final follow-up, there were no significant differences regarding the clinical and radiographic data. However, only the amount of the resected lateral bone was significantly lower in the study group than in the control group.

Conclusion: In young and active people with medial knee arthrosis, in whom the planned correction is $10^{\circ}$ or higher, we continue to suggest $\mathrm{CO}$ since it does not seem to influence the results of TKA negatively.

Keywords: Clinical scoring systems of The Knee Society, matched groups, primary total knee arthroplasty, total knee arthroplasty after combined high tibial osteotomy.

\section{ÖZ}

Amaç: Bu çalışmada önceki kombine yüksek tibial osteotomi (KO) sonrası total diz artroplasti (TDA)'lerinin sonuçları eşleştirilmiş bir primer TDA kontrol grubununkiler ile karşılaştırıldı.

Hastalar ve yöntemler: 01 Ağustos 200631 Aralık 2011 tarihleri arasında önceden KO geçiren 24 hastada (10 erkek, 14 kadın; ort. yaş 69.5 yıl; dağılım, 60-79 yıl) 24 ardışık çimentolu TDA uygulandı (çalışma grubu). Çalışma grubu aynı dönemde primer TDA uygulanan 24 hastalık bir kontrol grubu (10 erkek, 14 kadın; ort. yaş 69.9 yıl; dağılım, 63-79 yıl) ile karşılaştırıldı. Ameliyat öncesi ve sonrası Diz Derneği diz ve fonksiyon skoru ve hareket açıklığı belirlendi. Femorotibial açı, lateral subkondral plağa tanjan ve fibula başının üstü arasındaki mesafe, tibial kondilin transpozisyonu, patellar tendonun uzunluğu ve tibial eğim açısı ameliyat öncesinde ölçüldü. Son takipte, aynı parametreler hesaplandı ve lateral tibial kemik rezeksiyonunun miktarı belirlendi.

Bulgular: Ortalama takip süresi çalışma grubunda 97 ay (dağılım, 61-124 ay) ve kontrol grubunda 97 ay (dağılım, 61-123 ay) idi. Her iki grubun TDA sağkalım oranı \%100 idi. Son takipte, klinik ve radyolojik veriler açısından anlamlı farklılık yoktu. Fakat sadece rezeke edilen lateral kemik miktarı çalışma grubunda kontrol grubundan anlamlı olarak daha düşüktü.

Sonuç: Planlanan düzeltmenin $10^{\circ}$ veya daha yüksek olduğu, medial diz artrozlu genç ve aktif kişilerde TDA'nın sonuçlarını olumsuz etkilemediği görünen KO’yu önermeye devam ediyoruz.

Anahtar sözcükler: Diz Derneği klinik skorlama sistemleri, eşleştirilmiş gruplar, primer total diz artroplastisi, kombine yüksek tibial osteotomi sonrası total diz artroplastisi.

Received: May 02, 2019 Accepted: May 20, 2019 Published online: June 12, 2019

Correspondence: Miklós Papp, MD. PhD. Borsod County Teaching Hospital, Department of Orthopaedic Surgery 3526, Szentpéteri k. 72-76, Miskolc, Hungary. Tel: +3620 5616345 e-mail: drpapp62@gmail.com 
High tibial osteotomy (HTO) is a well-established procedure for treatment of the varus osteoarthritic knee. High tibial osteotomy produces satisfactory clinical results in the short-term but these results may deteriorate with time. ${ }^{[1-6]}$ Many patients who undergo HTO require total knee arthroplasty (TKA). ${ }^{[4,7,8]}$

Therefore, when setting up the indication of HTO, one should pay attention that HTO does not compromise the subsequent TKA and that the results do not deteriorate more rapidly compared to primary TKA alone. ${ }^{[9]}$

Earlier studies produced varying results for TKA after failed HTO. Several authors reported that the results of TKA in patients with a previous HTO were similar to those after primary TKA. ${ }^{[10-16]}$ Others have demonstrated inferior results of TKA after HTO with technical difficulties ${ }^{[5,9,17,18]}$ because of shortening of the patellar tendon and transposition of the tibial condyle caused by previous HTO.

According to our former studies, ${ }^{[19,20]}$ a combined high tibial osteotomy (CO) does not change considerably the position of the tibial condyle and the patella, thus we believe that $\mathrm{CO}$ does not compromise the subsequent TKA, hypothesizing that the clinical and radiological results and survivorship of TKA performed after failed $\mathrm{CO}$ are similar to primary TKA in the medium-to-long term. Therefore, in this study, we aimed to compare the results of TKAs performed after previous $\mathrm{CO}$ to those of a matched control group of primary TKA.

\section{PATIENTS AND METHODS}

This retrospective study was conducted at Department of Orthopaedic Surgery, Borsod County Teaching Hospital. Between 01 August 2006 and 31 December 2011, we performed 24 consecutive cemented TKAs in 24 patients (10 males, 14 females; mean age 69.5 years; range, 60 to 79 years) who had undergone previous CO (study group). The study group was compared to a control group of 24 patients (10 males, 14 females; mean age 69.9 years; range, 63 to 79 years) who were performed primary TKA during the same period. The study group was matched to the control group according to age, gender, weight, etiology, prosthetic design and duration of follow-up. The study protocol was approved by the Borsod County Teaching Hospital Ethics Committee. A written informed consent was obtained from each patient. The study was conducted in accordance with the principles of the Declaration of Helsinki.

We performed $\mathrm{CO}^{[1,20]}$ (combination of lateral closing and medial opening wedge osteotomy) in all cases in 1993. We preferred CO if the planned correction was $10^{\circ}$ or higher. ${ }^{[1,20]}$ Hardware was removed prior to TKA in all cases.

Preoperatively and at the final follow-up, the knees were evaluated according to the clinical scoring system of the Knee Society (knee and function score). ${ }^{[21]}$

Preoperatively, in both groups, we determined the anatomical femorotibial angle, the distance between the tangent to the lateral subchondral plate and the top of the fibular head and the amount of the transposition of the tibial condyle with respect to its bony axis on a preoperative weight-bearing anteroposterior radiograph. The transposition of the tibial condyle was calculated according to the method of Yoshida et al. ${ }^{[22]}$

In both groups, preoperative length of the patellar tendon was determined according to the method of Insall-Salvati ${ }^{[23]}$ and the tibial slope (TS) angle was determined according to the method of Bonnin $^{[24]}$ on a lateral radiograph. We determined the amount of lateral tibial bone resection as the difference of the following two values: the distance between the tangent to the lateral subchondral tibial plate and the top of the fibular head measured on preoperative weight-bearing anteroposterior radiograph and the distance between the tangent to the distal surface of the tibial component and the top of the fibular head measured on the radiograph taken in the third postoperative month. At the final follow-up, we evaluated the alignment and the TS in both groups.

The indication for conversion from CO to TKA and for primary TKA was increasing pain with radiological progression of osteoarthritis. In both groups, posterior cruciate retaining prosthesis (DePuy Synthes; P.F.C. SIGMA; Warsaw, Indiana, USA) was used in all cases without utilizing any patellar component. All knees were approached through the standard medial parapatellar incision. In both groups, we recorded the number of the release of different types.

The postoperative care was similar in both groups. On the first postoperative day, the patients started passive exercises with a continuous passive motion device and active exercises as well. Partial weightbearing was permitted on the fourth postoperative day and full-weight-bearing on the $10^{\text {th }}$ day.

\section{Statistical analysis}

Microsoft Excel 2007 and 2010 furthermore SysStat Sigmaplot 12.0 were used with the same results. Results of the study and the control groups were 
compared using the paired t-test. $P$ values below 0.05 were considered statistically significant.

\section{RESULTS}

There were no significant differences between the two groups regarding their preoperative demographic or clinical radiographic data. Only the distance between the tangent to the lateral tibial subchondral plate and the top of the fibular head was significantly less in the study group than in the control group $(\mathrm{p}=0.0000008)$ (Tables I, II, III).

More releases were required for soft tissue balancing in the study group (10 deep and 5 superficial medial collateral ligaments, 9 lateral retinacular releases) than in the control group (6 deep and 2 superficial medial collateral ligaments, 7 lateral retinacular releases).

TABLE I

Demographic data of patients

\begin{tabular}{lccc}
\hline & Mean & Range & $p$ \\
\hline Follow-up patient's group (months) & 97 & $61-124$ & - \\
Follow-up control group (months) & 97 & $61-123$ & - \\
Conversion interval (months) & 102 & $60-156$ & 0.80 \\
Age in patient's group (years) & 69.5 & $60-79$ & 0.82 \\
Age in control group (years) & 69.9 & $63-79$ & $22.20-37.87$ \\
Body mass index in patient's group (years) & 31.43 & $24-38.02$ & \\
Body mass index in control group (years) & 31.17 & & \\
\hline
\end{tabular}

TABLE II

Preoperative clinical data

\begin{tabular}{|c|c|c|c|}
\hline & Mean $\pm S D$ & F value & $p$ \\
\hline Knee Society knee score patient's group & $40.83 \pm 4.46$ & \multirow{2}{*}{0.94} & \multirow{2}{*}{0.87} \\
\hline Knee Society knee score control group & $41.04 \pm 4.53$ & & \\
\hline Knee Society function score patient's group & $41.67 \pm 9.29$ & \multirow{2}{*}{0.86} & \multirow{2}{*}{0.94} \\
\hline Knee Society function score control group & $41.88 \pm 8.95$ & & \\
\hline Flexion $\left({ }^{\circ}\right)$ patient's group & $109.2 \pm 8.0$ & \multirow{2}{*}{0.30} & \multirow{2}{*}{0.94} \\
\hline Flexion $\left(^{\circ}\right)$ control group & $109.0 \pm 10.0$ & & \\
\hline Flexion contracture $\left(^{\circ}\right)$ patient's group & $2.9 \pm 4.4$ & \multirow{2}{*}{0.79} & \multirow{2}{*}{0.87} \\
\hline Flexion contracture $\left(^{\circ}\right)$ control group & $2.7 \pm 4.2$ & & \\
\hline
\end{tabular}

SD: Standard deviation.

TABLE III

Preoperative radiological measurements

\begin{tabular}{lccc}
\hline & Mean \pm SD & F value & $p$ \\
\hline Tibial slope angle $\left(^{\circ}\right)$ patient's group & $6.3 \pm 2.5$ & 0.02 & 0.41 \\
Tibial slope angle $\left(^{\circ}\right)$ control group & $6.8 \pm 1.5$ & & \\
Alignment $(\mathrm{FTA})\left(^{\circ}\right)$ patient's group & $181.4 \pm 2.1$ & 0.23 & 0.82 \\
Alignment $(\mathrm{FTA})\left(^{\circ}\right)$ control group & $181.3 \pm 1.6$ & & 0.13 \\
Insall-Salvati ratio patient's group & $1.03 \pm 0.07$ & 0.71 & \\
Insall-Salvati ratio control group & $1.05 \pm 0.06$ & & 0.25 \\
Offset patient's group & $0.49 \pm 0.03$ & 0.15 & \\
Offset control group & $0.48 \pm 0.02$ & & \\
\hline
\end{tabular}

SD: Standard deviation; FTA: Femorotibial angle. 
TABLE IV

\begin{tabular}{|c|c|c|c|}
\hline \multicolumn{4}{|c|}{ Postoperative clinical data } \\
\hline & Mean \pm SD & F value & $p$ \\
\hline Knee Society knee score patient's group & $81.9 \pm 6.8$ & \multirow{2}{*}{0.96} & \multirow{2}{*}{0.65} \\
\hline Knee Society knee score control group & $82.8 \pm 6.9$ & & \\
\hline Knee Society function score patient's group & $71.5 \pm 7.1$ & \multirow{2}{*}{0.16} & \multirow{2}{*}{0.58} \\
\hline Knee Society function score control group & $72.5 \pm 5.3$ & & \\
\hline Flexion $\left({ }^{\circ}\right)$ patient's group & $106.9 \pm 8.1$ & \multirow{2}{*}{0.14} & \multirow{2}{*}{0.46} \\
\hline Flexion $\left(^{\circ}\right)$ control group & $109.0 \pm 11.0$ & & \\
\hline Flexion contracture $\left({ }^{\circ}\right)$ patient's group & $2.9 \pm 3.6$ & \multirow{2}{*}{0.68} & \multirow{2}{*}{0.83} \\
\hline Flexion $\left(^{\circ}\right)$ contracture control group & $2.7 \pm 3.3$ & & \\
\hline
\end{tabular}

SD: Standard deviation.

TABLE V

\begin{tabular}{|c|c|c|c|}
\hline \multicolumn{4}{|c|}{ Postoperative radiological measurements } \\
\hline & Mean $\pm S D$ & F value & $p$ \\
\hline Tibial slope angle $\left({ }^{\circ}\right)$ patient's group & $3.78 \pm 1.45$ & \multirow{2}{*}{0.49} & \multirow{2}{*}{0.84} \\
\hline Tibial slope angle $\left({ }^{\circ}\right)$ control group & $3.70 \pm 1.27$ & & \\
\hline Alignment valgus $\left({ }^{\circ}\right)$ patient's group & $4.9 \pm 1.9$ & \multirow{2}{*}{0.94} & \multirow{2}{*}{0.10} \\
\hline Alignment valgus $\left({ }^{\circ}\right)$ control group & $5.8 \pm 1.9$ & & \\
\hline
\end{tabular}

SD: Standard deviation.

To restore the preosteotomy position of the lateral joint line in the study group, we used $10 \mathrm{~mm}$ or thicker tibial insert in $54.2 \%$ of the cases, while in the remaining $45.8 \%, 8 \mathrm{~mm}$ thick insert was sufficient. In the control group, we used $8 \mathrm{~mm}$ thick tibial insert in 21 cases and $10 \mathrm{~mm}$ thick tibial insert in three cases. There were no postoperative complications in either group. No patient required revision of the TKA components during the duration of follow-up.

At the time of the final follow-up, there were no significant differences regarding clinical or radiological data. (Tables IV, V). However, lesser lateral bone was resected in the study group than in the control group (5.11 [range, 2-10] vs. 8.42 [range, 8-12]) $(\mathrm{p} \leq 0.05)$ (Tables III, IV).

\section{DISCUSSION}

During subsequent conversion to TKA after osteotomy, the soft tissue scarring and the shortening of the patellar tendon make the subperiosteal exposure of the proximal tibia and eversion of the patella more difficult with the additional risk of avulsing of the tibial tubercle. ${ }^{[4,1618,25]}$ During the exposure, the rectus snip, V-Y plasty of quadriceps and tibial tubercle osteotomy may be required. ${ }^{[16,18,26,27]}$
No additional procedure for eversion of the patella was needed in any case. The distance between the tibial tubercle and the joint line does not change after $\mathrm{CO}$ and thus the length of patellar tendon does not change significantly. ${ }^{[19,20]}$

Excessive undercorrection, overcorrection and rotational deformity are not uncommon after a failed $\mathrm{HTO}^{[14,28]}$ and the HTO inevitably produces some transposition of the tibial condyle with respect to its bony axis. ${ }^{[29]}$ These factors can lead to difficulty in obtaining optimal soft tissue balancing, appropriate alignment and optimal positioning of the tibial component during the subsequent TKA ${ }^{[15,18,30]}$

In our study, similar to Meding et al., ${ }^{[30]}$ the impingement of the peg of the tibial component against the truncated lateral metaphysis did not occour, the tibial component was not medialized or downsized in any case, because the $\mathrm{CO}$ does not lead to significant lateral tibial bone loss and to lateral overhang. ${ }^{[19]}$

After HTO, reduced amount of bone stock can be present on the lateral side of the tibial condyle. Because of the lateral bone loss, only minimal lateral tibial bone can be resected during the subsequent TKA. To restore the preosteotomy lateral joint line position, 
the use of a relatively thicker tibial component is necessary. ${ }^{[14,16,18,30]}$

Similar to Meding et al., ${ }^{[14,15,30]}$ we resected significantly less lateral tibial bone in the study group than in the control group. Furthermore, the HTO usually changes the TS angle and may weaken the attachment of the posterior cruciate ligament (PCL). ${ }^{[15-20,31-33]}$

We did not note the tenuous PCL in any case in the study group, because the $\mathrm{CO}$ does not weaken the distal insertion of the PCL significantly and the TS decreases only in a small degree after $\mathrm{CO} .^{[19,20]}$

We aimed for a postoperative alignment of $6^{\circ}$ valgus in both groups. In the study group, we noticed slight undercorrection, while $66.66 \%$ of cases was in the range of $4-8^{\circ}$ of valgus.

Our study confirmed our hypothesis, showing similar knee and function score in both groups at the time of the final follow-up and a $100 \%$ survivorship of total knee arthroplasty in both groups. ${ }^{[34]}$ Similar to Badawy et al., ${ }^{[35]}$ we detected no higher risk of revision in the study group than in the control group.

Some authors investigated the results of TKA after closing wedge osteotomy (CWO) $)^{[10,12-16,27,30,35]}$ while others investigated the results of TKA after opening wedge osteotomy (OWO). ${ }^{[17,27,36]}$ The results of TKA indicated after $\mathrm{CWO}$ as well after OWO are similar to the ones of primaer TKA. ${ }^{[9,10,11,14,16]}$ There were no significant differences between the groups underwent TKA after CWO or OWO. ${ }^{[9,27,35]}$ Lateral bone loss and lateral overhang were common findings in the postCWO group. ${ }^{[10,14,35]}$ The TS was reported to decline after $\mathrm{CWO}^{[10,16]}$ and to increase after OWO. ${ }^{[17]}$ Patella infera was reported both in the post-CWO and the post-OWO studies. ${ }^{[10,17]}$ To comparison in our study group there was no lateral bone loss, significant change in TS or patella infera.

The limitations of this study are its small sample size and retrospective design. However, to our knowledge, this is the first study in the literature that elaborates the TKA long-term results after high tibial osteotomy (CO).

In conclusion, in young and active people with medial knee arthrosis, we continue to suggest $\mathrm{CO}$ since previous $\mathrm{CO}$ in the medium-long term does not seem to influence the results of TKA negatively.

\section{Declaration of conflicting interests}

The authors declared no conflicts of interest with respect to the authorship and/or publication of this article.

\section{Funding}

The authors received no financial support for the research and/or authorship of this article.

\section{REFERENCES}

1. Akasaki Y, Matsuda S, Miura H, Okazaki K, Moro-oka TA, Mizu-uchi $\mathrm{H}$, et al. Total knee arthroplasty following failed high tibial osteotomy: mid-term comparison of posterior cruciate-retaining versus posterior stabilized prosthesis. Knee Surg Sports Traumatol Arthrosc 2009;17:795-9.

2. Bonasia DE, Dettoni F, Sito G, Blonna D, Marmotti A, Bruzzone $M$, et al. Medial opening wedge high tibial osteotomy for medial compartment overload/arthritis in the varus knee: prognostic factors. Am J Sports Med 2014;42:690-8.

3. Efe T, Ahmed G, Heyse TJ, Boudriot U, Timmesfeld N, Fuchs-Winkelmann $\mathrm{S}$, et al. Closing-wedge high tibial osteotomy: survival and risk factor analysis at long-term follow up. BMC Musculoskelet Disord 2011;12:46.

4. Insall JN, Joseph DM, Msika C. High tibial osteotomy for varus gonarthrosis. A long-term follow-up study. J Bone Joint Surg [Am] 1984;66:1040-8.

5. Niinimäki TT, Eskelinen A, Mann BS, Junnila M, Ohtonen P, Leppilahti J. Survivorship of high tibial osteotomy in the treatment of osteoarthritis of the knee: Finnish registry-based study of 3195 knees. J Bone Joint Surg [Br] 2012;94:1517-21.

6. Song SJ, Bae DK, Kim KI, Lee CH. Conversion total knee arthroplasty after failed high tibial osteotomy. Knee Surg Relat Res 2016;28:89-98.

7. Preston S, Howard J, Naudie D, Somerville L, McAuley J. Total knee arthroplasty after high tibial osteotomy: no differences between medial and lateral osteotomy approaches. Clin Orthop Relat Res 2014;472:105-10.

8. Robertsson $\mathrm{O}, \mathrm{W}$-Dahl A. The risk of revision after TKA is affected by previous HTO or UKA. Clin Orthop Relat Res 2015;473:90-3.

9. Haslam P, Armstrong M, Geutjens G, Wilton TJ. Total knee arthroplasty after failed high tibial osteotomy long-term follow-up of matched groups. J Arthroplasty 2007;22:245-50.

10. Amendola L, Fosco M, Cenni E, Tigani D. Knee joint arthroplasty after tibial osteotomy. Int Orthop 2010;34:289-95.

11. W-Dahl A, Robertsson O. Similar outcome for total knee arthroplasty after previous high tibial osteotomy and for total knee arthroplasty as the first measure. Acta Orthop 2016;87:395-400.

12. El-Galaly A, Nielsen PT, Jensen SL, Kappel A. Prior high tibial osteotomy does not affect the survival of total knee arthroplasties: results from the danish knee arthroplasty registry. J Arthroplasty 2018;33:2131-5.

13. Kazakos KJ, Chatzipapas C, Verettas D, Galanis V, Xarchas KC, Psillakis I. Mid-term results of total knee arthroplasty after high tibial osteotomy. Arch Orthop Trauma Surg 2008;128:167-73.

14. Meding JB, Keating EM, Ritter MA, Faris PM. Total knee arthroplasty after high tibial osteotomy. A comparison study in patients who had bilateral total knee replacement. J Bone Joint Surg [Am] 2000;82:1252-9.

15. Meding JB, Wing JT, Ritter MA. Does high tibial osteotomy affect the success or survival of a total knee replacement? Clin Orthop Relat Res 2011;469:1991-4. 
16. van Raaij TM, Bakker W, Reijman M, Verhaar JA. The effect of high tibial osteotomy on the results of total knee arthroplasty: a matched case control study. BMC Musculoskelet Disord 2007;8:74.

17. Erak S, Naudie D, MacDonald SJ, McCalden RW, Rorabeck $\mathrm{CH}$, Bourne RB. Total knee arthroplasty following medial opening wedge tibial osteotomy: technical issues early clinical radiological results. Knee 2011;18:499-504.

18. Windsor RE, Insall JN, Vince KG. Technical considerations of total knee arthroplasty after proximal tibial osteotomy. J Bone Joint Surg [Am] 1988;70:547-55.

19. Papp M, Csernátony Z, Kazai S, Károlyi Z, Róde L. The patella and tibial condyle position after combined and after closing wedge high tibial osteotomy. Knee Surg Sports Traumatol Arthrosc 2007;15:769-80.

20. Papp M, Szabó L, Lázár I, Takács I, Károlyi Z, Nagy $\mathrm{GG}$, et al. Combined high tibial osteotomy decreases biomechanical changes radiologically detectable in the sagittal plane compared with closing-wedge osteotomy. Arthroscopy. 2009;25:355-64.

21. Insall JN, Dorr LD, Scott RD, Scott WN. Rationale of the Knee Society clinical rating system. Clin Orthop Relat Res 1989;248:13-4.

22. Yoshida $\mathrm{K}$, Ashada $\mathrm{K}$, Onode $\mathrm{Y}$. The influence of previous high tibial osteotomy on total knee replacement. Jpn J Rheum Joint Surg 1987;6:491-98.

23. Insall J, Salvati E. Patella position in the normal knee joint. Radiology 1971;101:101-4.

24. Bonnin M. La subluxation tibiale antérieure en appui monopodal daus la rupture du LCA. Etude clinique et Bio $\neg$ mécanique. Lyon: Thése Médicine; 1990.

25. Bin SI, Kim HJ, Ahn HS, Rim DS, Lee DH. Changes in patellar height after opening wedge and closing wedge high tibial osteotomy: a meta-analysis. Arthroscopy 2016;32:2393-2400.

26. Bae DK, Song SJ, Yoon KH. Total knee arthroplasty following closed wedge high tibial osteotomy. Int Orthop 2010;34:283-7.

27. Bastos Filho R, Magnussen RA, Duthon V, Demey G,
Servien E, Granjeiro JM, et al. Total knee arthroplasty after high tibial osteotomy: a comparison of opening and closing wedge osteotomy. Int Orthop 2013;37:427-31.

28. Farfalli LA, Farfalli GL, Aponte-Tinao LA. Complications in total knee arthroplasty after high tibial osteotomy. Orthopedics 2012;35:464-8.

29. Nakamura E, Mizuta H, Kudo S, Takagi K, Sakamoto K. Open-wedge osteotomy of the proximal tibia with hemicallotasis. J Bone Joint Surg [Br] 2001;83:1111-5.

30. Meding JB, Keating EM, Ritter MA, Faris PM. Total knee arthroplasty after high tibial osteotomy. Clin Orthop Relat Res 2000;375:175-84.

31. Akamatsu Y, Kobayashi H, Kusayama Y, Kumagai K, Saito T. Comparative study of opening-wedge high tibial osteotomy with and without a combined computed tomographybased and image-free navigation system. Arthroscopy 2016;32:2072-81.

32. Whitehead TS, Willits K, Bryant D, Giffin JR, Fowler PJ. Impact of medial opening or lateral closing tibial osteotomy on bone resection and posterior cruciate ligament integrity during knee arthroplasty. J Arthroplasty 2009;24:979-89.

33. Walther M, König A, Kirschner S, Gohlke F. Results of posterior cruciate-retaining unconstrained total knee arthroplasty after proximal tibial osteotomy for osteoarthritis. A prospective cohort study. Arch Orthop Trauma Surg 2000;120:166-70.

34. Atik OŞ. Which articles do we prefer to publish? Eklem Hastalik Cerrahisi 2018;29:1.

35. Badawy M, Fenstad AM, Indrekvam K, Havelin LI, Furnes $\mathrm{O}$. The risk of revision in total knee arthroplasty is not affected by previous high tibial osteotomy. Acta Orthop 2015;86:734-9.

36. Kuwashima U, Tashiro Y, Okazaki K, Mizu-Uchi H, Hamai $\mathrm{S}$, Murakami K, et al. Comparison of the impact of closing wedge versus opening wedge high tibial osteotomy on proximal tibial deformity and subsequent revision to total knee arthroplasty. Knee Surg Sports Traumatol Arthrosc 2017;25:869-75. 